\title{
A Copa do Mundo e a modernização dos estádios brasileiros.
}

\author{
Rafael Rangel Soffredi \\ Orientador: Doutor Edson Silva de Farias \\ Dissertação de Mestrado \\ Data da defesa: 09.12.2011
}

N essa pequisa, de modo geral, abordo a influência que um evento como a Copa do Mundo de Futebol exerce sobre um país como o Brasil. De modo específico, analiso os critérios que influenciaram na escolha dos estádios brasileiros que seriam modernizados devido à Copa do Mundo e como se deu essa escolha levando-se em conta os vários interesses envolvidos. Faço uma análise também a respeito da opinião de alguns torcedores da cidade de São Paulo sobre alguns aspectos da modernização dos estádios e outras influências da recente modernização no futebol. A escolha pela cidade de São Paulo como alvo dessa pesquisa se dá devido à preferência da Fédération Internationale Football Association (Fifa) e do Comitê Organizador Local (COL) da Copa, presidido por Ricardo Teixeira, também presidente da Confederação Brasileira de Futebol (CBF), pela cidade como palco do jogo de abertura da Copa e pela importância econômica e política de São Paulo no cenário nacional. A importância política e, principalmente, econômica de São Paulo foi o que fez com que a cidade se tornasse a preferida pela Fifa para abrigar o jogo de abertura da Copa. Uma vez que esse jogo é encarado como o mais importante de toda a competição, até mesmo do que o jogo final, ao menos financeiramente falando. Por outro lado, vimos que, apesar de certas premissas presentes na ideia de modernização e na influência que os modelos europeus exercem nessa ideia sobre outros países do globo, o que mais pesou na decisão sobre a modernização dos estádios brasileiros para a Copa foram as disputas internas de interesses. Vimos também que os torcedores brasileiros, e parte da população em geral, apesar de concordarem com alguns aspectos da modernização, ainda não estão totalmente dispostos a arcar financeiramente com ela. Ou seja, além de uma consciência característica, é necessário que haja também uma base material sólida para que determinados aspectos do futebol moderno, do modelo europeu, venham a se desenvolver no futebol brasileiro.

Palavras-chave: Modernização, Copa do Mundo, Estádios de Futebol. 